\title{
四肢・躯幹部骨折を伴う腹腔臓器損傷例の検討
}

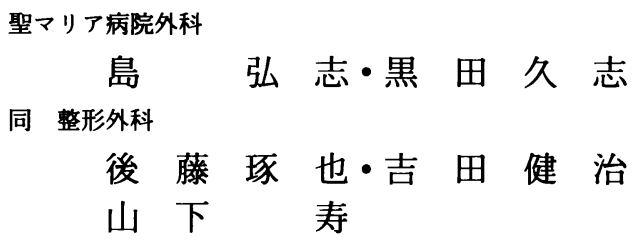

\section{Examination of Abdominal Injuries with Fracture of Extremities and Trunk}

\author{
Hiroji Shima, Hisashi Kuroda, Takuya Goto, \\ Kenzi Yoshida and Hisashi Yamashita \\ Department of Surgery and Orthopaedic Surgery, St. Mary Hospital
}

\begin{abstract}
Twenty four abdominal injury cases with bone fracture of the extremities and trunk were examined retrospectively from January 1994 to December 1997.

We considered the increaed level of transaminase and the fracture of the ribs on the lower right side of the body, and its relation to the damaged liver. On the other hand, we think it is important to consider the relation between the fracture of the ribs on the lower left side of the body and the damage to the spleen.

The fusion of the bones is considered an important factor for ensuring the well being of the whole body and recovery. It is thus necessary to perform this operation as soon as possible after accidents.
\end{abstract}

Key words : Multiple injury (多発外傷), bone fracture (骨折), abdominal injury (腹部損傷)

はじめに

交通量の增加に伴い, 交通事故による多発外傷の治 療も多く経験するようになった，今回，我々は四肢・ 躯幹部骨折を伴う腹腔臓器損傷例の原因, 損傷部位, 手術等について検討した.

\section{対}

1994 年 1 月から 1997 年 12 月迄の 4 年間に, 当院 外科及び整形外科で入院治療を行った交通外傷による 四肢・躯幹部骨折を伴った腹腔荿器損傷例は 24 例有 り, 年齢は 15 歳加 70 歳迄の平均 35.5 歳, 男性 18 例, 女性 6 例であった.
結果

受傷原因としては, 自動車走行中が 10 例 (41.7\%) と最も多く, 次いで自動二輪車走行中が 9 例 (37.5\%), 歩行中が 5 例 (20.8\%) であった（図 1 ). 骨折部位 としては肋骨骨折が 13 例 (54.2\%) と最も多く見ら れ, 次いで下腿 7 例 (29.2\%), 大腿 (25\%), 骨盤 （25\%）と骨盤下肢に多く，多発骨折は 7 例であった。 損傷臓器は肝臟が 15 例之最も多く, 脾臓 5 例, 腎臟 3 例, 小腸 3 例, 大網 1 例, 横隔膜 1 例で, 留損傷例 と大網損傷例は全例肝損傷を伴っていた（表 1 ）。肝 損傷例で, 右側肋骨骨折のある 4 例は, いずれす第 7 肋骨以下の下位胁骨骨折を伴っていた。 損傷形態は, 
日本外傷学会肝損傷分類 ${ }^{4)}$ で，被膜下血腫（Ｉ a） 5 例, 中心性破裂（Ｉ b） 8 例，樑在性損傷（III b） 2 例であり，全例トランスアミラーゼは $100 \mathrm{IU} / 1$ を越 えていた．肝損傷に対する手術例は無く，2 例に経力 テーテル的動脈塞栓術（T. A. E.）を施行した（表 2 ）.

\section{[症 例 1]}

19 歳, 男性, 左大腿骨骨折.

$250 \mathrm{cc}$ の自動二輪車で走行中に乗用車に衝突し受傷.

搬入時バイタルは，血圧 $130 / 70 \mathrm{mmHg}$ ，脈拍数 96/

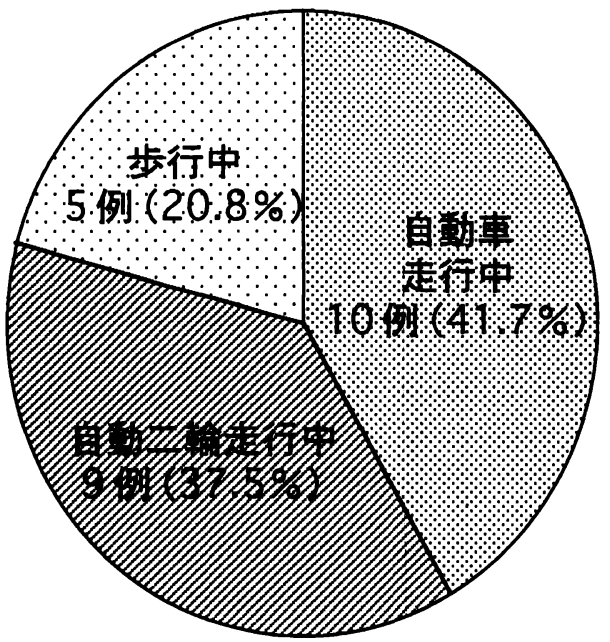

図1 受傷原因
分, 呼吸数 $22 /$ 分, 体温 $35.2{ }^{\circ} \mathrm{C}$, 意識正常. 血液生化 学検查では WBC $13,100 / \mathrm{mm}^{3}, \mathrm{RBC} 480 \times 10^{4} / \mathrm{mm}^{3}$, $\mathrm{Hgb} 14.8 \mathrm{~g} / \mathrm{dl}$, Ht 43.3\%, GOT $1262 \mathrm{IU} / 1$, GPT $1914 \mathrm{IU} / 1, \mathrm{LDH} 3531 \mathrm{IU} / 1$. トランスアミナーゼの 著明な上昇により，肝損傷を疑い超音波検査， CT 検 查を行って, 中心性破裂（I b) と診断したが, CT 検查で明らかな造影剤漏出を認めた為（図 2 ), 直ち に血管造影を行い，T.A.E. を行った（図 3 ）。 全身状態の改善を待ち, 受傷後 20 日目に骨接合術を 施行, 軽快退院した。

脾損傷例は全例左側下位肋骨骨折を伴っており， 3 例にT.A.E. を行ったが手術施行例は無かった（表 3 ）. 腎損傷例は肝損傷を伴っていたが，いずれも軽

表 1 四肢・躯幹部骨折部位及び腹腔脿器損賃部位

\begin{tabular}{|c|c|c|c|}
\hline 鎖骨 & 1 例 & 肝炡 & 15 例 ${ }^{3}$ 例 \\
\hline 肩甲骨 & 1 例 & & \\
\hline 胸骨 & 1 例 & & \\
\hline 胁骨 & 13 例 & 朝被 & 5 例 \\
\hline 前腕骨 & 4 例 & & \\
\hline 上脆骨 & 2 例 & 腎蓓 & 3 例 \\
\hline 腰椎 & 2 例 & & \\
\hline 骨盤 & 6 例 & & \\
\hline 大腿骨 & 6 例 & 小腸 & 3 例 \\
\hline 膝蓋骨 & 2 例 & & \\
\hline 下腿骨 & 7 例 & 大網 & 1 例 \\
\hline 足根骨 & 1 例 & & \\
\hline 多発骨折 & 7 例 & 横隔膜 & 1 例 \\
\hline
\end{tabular}

表 2 肝損傷例

\begin{tabular}{|c|c|c|c|c|}
\hline 症例 & 右胁骨骨折部位 & 損傷形態 & GOT/GPT & 治療 \\
\hline 1 & $(-)$ & 被膜下血腫（Ｉ a） & $215 / 217$ & 経過観察 \\
\hline 2 & 第 7 肋骨 & " & $309 / 251$ & $"$ \\
\hline 3 & $(-)$ & " & $101 / 151$ & " \\
\hline 4 & $(-)$ & " & $322 / 311$ & " \\
\hline 5 & $(-)$ & " & $1550 / 878$ & " \\
\hline 6 & 第 $10,11,12$ 肋骨 & 中心性破裂（I b） & $404 / 366$ & " \\
\hline 7 & $(-)$ & " & $245 / 155$ & " \\
\hline 8 & $(-)$ & " & $836 / 772$ & $"$ \\
\hline 9 & $(-)$ & " & $763 / 587$ & " \\
\hline 10 & $(-)$ & " & $107 / 243$ & " \\
\hline 11 & 第 $5,6,7,8,9$ 肋骨 & " & $207 / 120$ & " \\
\hline 12 & $(-)$ & " & $562 / 510$ & " \\
\hline 13 & $(-)$ & " & $1262 / 1914$ & T. A. E. \\
\hline 14 & $(-)$ & 深在性損傷（III b） & $431 / 240$ & 経過観察 \\
\hline 15 & 第 8 肋骨 & $"$ & $542 / 500$ & T. A. E. \\
\hline
\end{tabular}


度の損傷であった（表 4 ）。

開腹手術は 5 例 $(28.3 \%)$ に行った. 内訳は小腸穿孔 3 例, 大網からの出血 1 例, 左横隔膜ヘルニア 1 例で あった．小腸穿孔例及び横隔膜損傷例は受傷当日に緊 急手術を行ったが, 大網出血例は, 腹部所見, 進行す る貧血により 2 日後に手術を行った（表 5 ）.

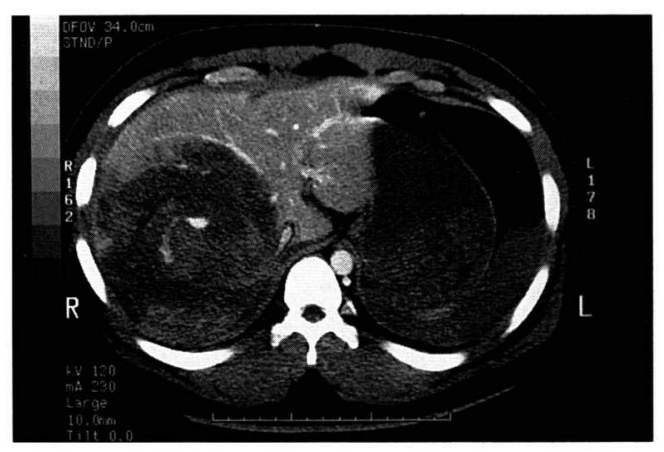

図 2 腹部 $\mathrm{CT}$

肝右葉に大きな low density の部を認め, 肝損傷 ( I b) と診断

中央に造影剂の漏出を認め, 出血が持続していると 判断した.

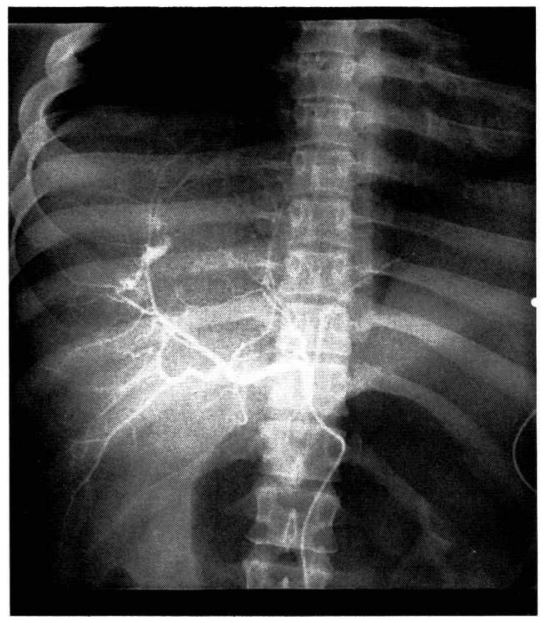

(A)

\section{[症 例 2]}

57 歳, 男性, 左第 $2,3,4,5$ 肋骨骨折, 右膝蓋骨 骨折.

軽ライトバン後部座席乗車中, 乗用車と衝突し受傷. 搬入時バイタルは, 血圧 $110 / 62 \mathrm{mmHg}$, 脈拍数 64/ 分, 呼吸数 $26 /$ 分, 意識正常. 血液生化学検査では WBC $9,900 / \mathrm{mm}^{3}$ と軽度上昇を認めるが貧血は無い. 血液ガス検查で $\mathrm{PO}_{2} 59 \mathrm{mmHg}, \mathrm{PCO}_{2} 41.5 \mathrm{mmHg}$, $\mathrm{O}_{2 \mathrm{SAT}} 90.7 \%$, B. E. $2.6 \mathrm{mmol} / \mathrm{L}$ と低酸素血症を認め, 胸部単純写真で左肺野の透過性低下がある事により, 胁骨骨折に伴う血胸と判断し, 胸腔ドレーンを挿入, 血液ガスの改善を認めたが, ドレーン挿入後の胸部単 純写真でガス像を認め (困 4), 胸部 CT 検査を行い (図 5 ), 外傷性横隔膜ヘルニアの診断で当日緊急手術 を行った。術後経過は良好で軽快退院した。

考察

交通外傷では, 鈍的外力が四肢・躯幹に強く作用し, 多発外傷の形態をとる事が多く, 診断及び治療には充 分な知識, 経験が要求される ${ }^{3)}$. 腹部蔵器損傷の診断 に関しては, 視, 触診による腹部所見の観察に加え,

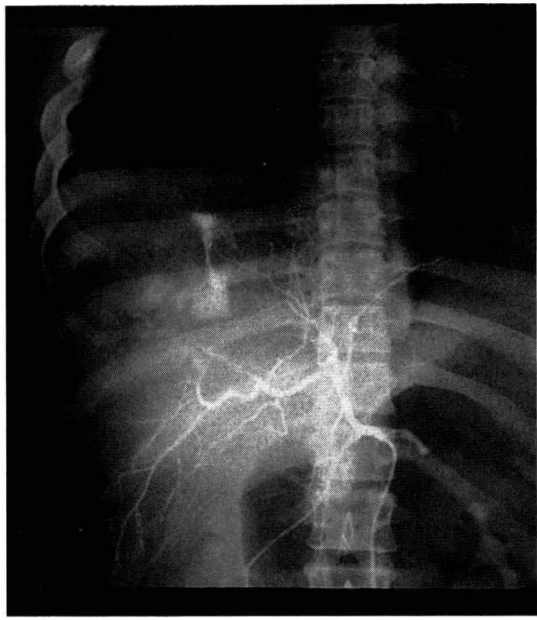

(B)

図 3 腹部血管造影

（A） $\mathrm{S}$ 、に extravasation を認めた

（B） T. A. E，を行い造影剤眝留を認めるが， extravasationの消失を確認した。 
衰 3 脾損傷例

\begin{tabular}{|c|c|c|c|c|}
\hline 症例 & 左胁骨骨折部位 & 損賃形態 & GOT/GPT & 治療 \\
\hline 1 & 第 7,8 肋骨 & 被膜下損笏（I） & $19 / 5$ & 経過観察 \\
\hline 2 & 第 8,9 肋骨 & 単純型実質損傷（IIIa） & $32 / 28$ & " \\
\hline 3 & 第 $8,9,10$ 肋骨 & 離断型実質損賃（III b) & $52 / 66$ & T. A. E. \\
\hline 4 & 第 12 肋骨 & 粉砕型実質損傷（IIId） & $69 / 57$ & " \\
\hline 5 & 第 7 肋骨 & 粉砕型実質損傷（IIId） & $70 / 60$ & " \\
\hline
\end{tabular}

表 4 焣損賃例

\begin{tabular}{|c|c|c|c|}
\hline 症例 & 損賃状態 & 骨折部位 & 他㼨器損偖 \\
\hline 1 & $\begin{array}{c}\text { 被膜下血腫 } \\
\quad(\text { I b })\end{array}$ & $\begin{array}{l}\text { 右大腿骨骨折 } \\
\text { 左肩甲骨折 } \\
\text { 左鎖骨骨折 }\end{array}$ & $\begin{array}{c}\text { 両㑡肺挫稘 } \\
\text { 肝損偒 }\end{array}$ \\
\hline 2 & " & 骨盤骨折 & 肝損儌 \\
\hline 3 & " & 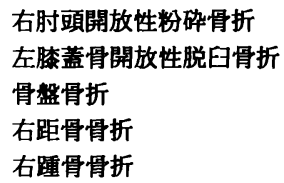 & 肝損偤 \\
\hline
\end{tabular}

衰 5 開腹手術例

\begin{tabular}{|c|c|c|c|}
\hline 症例 & 腹腔滕器損賃部位 & 骨折部位 & 手術術式 \\
\hline 1 & $\begin{array}{l}\text { 小腸 } \\
\text { II b }(\mathrm{O}) \times 3\end{array}$ & $\begin{array}{l}\text { 左第 } 3,4 \text { 肋骨骨折 } \\
\text { 胸骨骨折 } \\
\text { 右足関節内果骨折 }\end{array}$ & 小晹部分切除 \\
\hline 2 & $\begin{array}{l}\text { 小腸 } \\
\text { III } \mathrm{b}\left(\mathrm{A}, \mathrm{V}_{1}\right)+\mathrm{II} \mathrm{b}(\mathrm{A}) \times 4\end{array}$ & 左脛骨骨折 & 小腸部分切除 \\
\hline 3 & $\begin{array}{l}\text { 小腸 } \\
\mathrm{II} \mathrm{b}(\mathrm{A})+\mathrm{II}(\mathrm{O}) \times 2\end{array}$ & $\begin{array}{c}\text { 右大腿骨骨折 } \\
\text { 右前腕骨骨折 } \\
\text { （橈骨, 尺骨） }\end{array}$ & 小腸部分切除 \\
\hline 4 & $\begin{array}{l}\text { 大網 } \\
\text { 肝 ( I a) }\end{array}$ & $\begin{array}{l}\text { 右骨盤骨折 } \\
\text { (䎵骨, 腸骨) }\end{array}$ & 止血術 \\
\hline 5 & 左横隔膜 & $\begin{array}{l}\text { 左第 } 2,3,4,5 \text { 助骨骨折 } \\
\text { 右膝蓋骨骨折 }\end{array}$ & $\begin{array}{c}\text { 横隔膜閉鎖術 } \\
\text { (単純閉鎖) }\end{array}$ \\
\hline
\end{tabular}

腹部単純写真により得られる情報は多いが, より客観 的に損傷部位, 出血量を診断する為に腹部超音波検查, $\mathrm{CT}$ 検查が必要である ${ }^{1)}$. 我々の施設では, 消化管穿 孔を強く疑う場合にのみ, 腹腔穿刺や腹腔洗浄を行っ ている，治療を行うに際しては, 先ず呼吸, 循環動態 意識レベルを把握した後に，緊急度の高いものから優 先順位を考虑すべきで, 原則として, 胸部外傷による 呼吸循環障害, 腹部外傷による出血性ショック, 頭部 外傷による意識障害, 四肢・躯幹部の創傷, 骨折の順
に治療を行っている ${ }^{2)}$. 腹部実質臟器損傷例では超音 波検査, CT 検查で損傷形態が把握出来る為, T. A E. を行う事で不要な開腹手術は激減したが，消化管穿孔 を伴わない大網，腸間膜出血に関してはバイタルチェッ ク, 血液生化学検査値, 画像検査での出血量の変化を 経時的に観察し，手術を常に考虑しておかなければな らない，我々の施設では，骨折治療の時期は，原則と して 1 週間前後としている. 今回，検討した 24 例で は，受傷当日に開腹手術を前提とした骨接合術，創外 


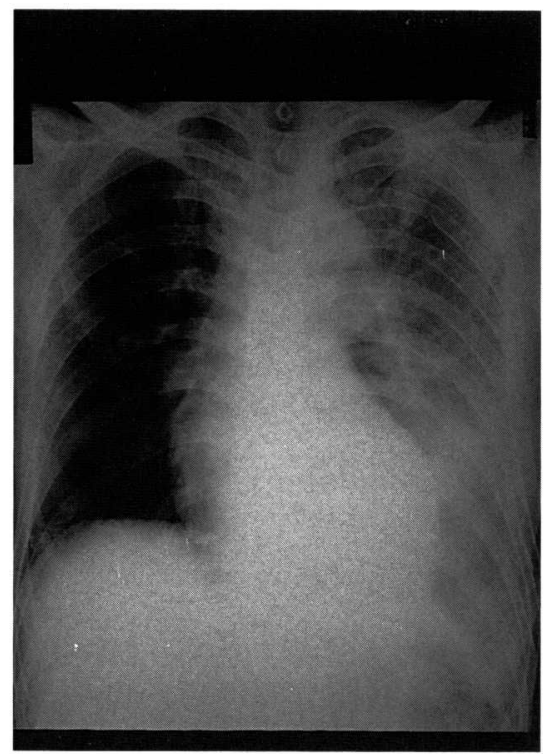

(A)

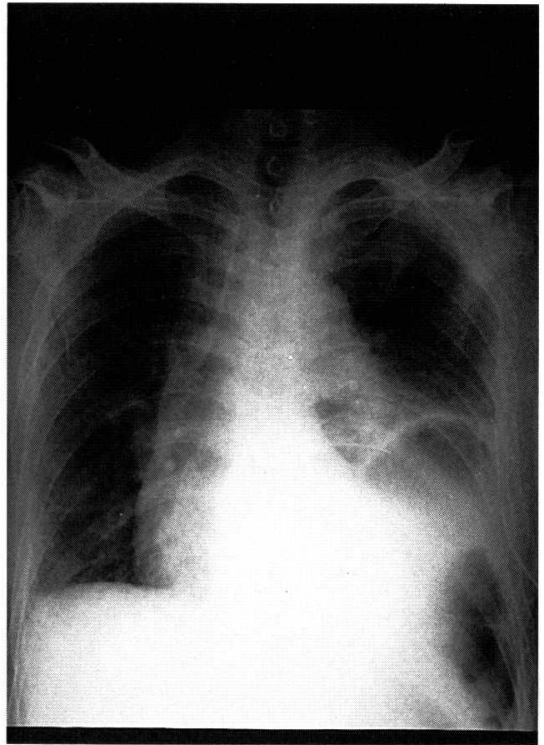

(B) 腹腔ドレーン㨂入後の胸部単純写真

図 4 搬入直後の胸部単純写真

（A）左側肺野の透過性の低下を認め, 血胸と診断.

（B）左下肺野にガス像を認め，腸管脱出を疑う.

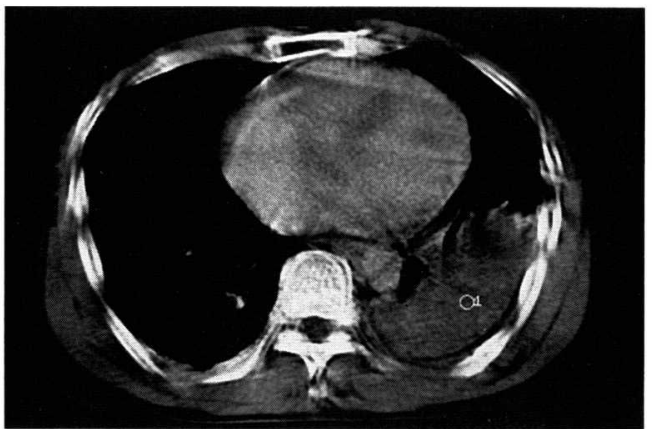

図 5 胸部 CT

左肺野に脾蔵の脱出を認め, 外傷性左横隔膜ヘルニ アと診断.

固定を各 1 例ずつ行っているが, 治療経過中に施行し た 10 例の骨接合術は, 受傷後 3 日目から最長 44 日目 に行っており, 平均 16 日であった. 骨折以外の損傷 による全身状態改善に日数を要した為と思われる.

$$
\text { ま と め }
$$

1. 過去 4 年間に四肢・躯幹部骨折を伴う腹腔臟器
損傷例を 24 例経験した。

2. 右側下位肋骨骨折でトランスアミラーゼ值 100 IU/1 以上の症例では肝損傷を疑い，左側下位肋骨骨 折では脾損傷を考虑する必要がある.

3. 腹腔臓器損傷例では, 損傷部位, 出血量の同定 を超音波検査, CT 検査で行い, 必要に応じて T. A. E. を行う事で, 肝, 腎, 脾損傷に対する不要な開腹 手術を無くす事が可能となった。

4. 骨折に対する骨接合術の時期は, 緊急を要しな い事が多く, 全身状態の改善を待って施行している.

\section{参考 文 献}

1）遠藤幸男，小林国男：外傷性腹部実質淢器損傷の診断 と治療; 最近の進歩. 消化器外科, $18: 1777-1785$, 1995.

2）北野光秀ほか：腹部外傷からみた多発外傷治療の優先 順位. 救急医学, 19:765-769, 1995.

3）黒川 顕：新鮮外傷における救急処置. 日本医事新報, 3699 : 43-49, 1995.

4）日本外傷学会肝損傷分類委員会：日本外傷学会肝損傷 分類. 日外傷会誌, $8: 297-298,1994$. 